\title{
Hemosporidian blood parasites in seabirds - a comparative genetic study of species from Antarctic to tropical habitats
}

\author{
Petra Quillfeldt • Javier Martínez • Janos Hennicke • \\ Katrin Ludynia • Anja Gladbach • Juan F. Masello • \\ Samuel Riou $\cdot$ Santiago Merino
}

Received: 21 May 2010 /Revised: 7 July 2010 / Accepted: 7 July 2010 / Published online: 23 July 2010

(C) The Author(s) 2010. This article is published with open access at Springerlink.com

\begin{abstract}
Whereas some bird species are heavily affected by blood parasites in the wild, others reportedly are not. Seabirds, in particular, are often free from blood parasites, even in the presence of potential vectors. By means of polymerase chain reaction, we amplified a DNA fragment from the cytochrome b gene to detect parasites of the genera Plasmodium, Leucocytozoon, and Haemoproteus in 14 seabird species,
\end{abstract}

P. Quillfeldt $(\bowtie) \cdot$ K. Ludynia $\cdot$ A. Gladbach $\cdot$ J. F. Masello

Max-Planck-Institut für Ornithologie, Vogelwarte Radolfzell,

Schlossallee 2,

78315 Radolfzell, Germany

e-mail: petra.quillfeldt@gmx.de

J. Martínez

Departamento de Microbiología y Parasitología,

Universidad de Alcalá, Alcalá de Henares,

Madrid, Spain

J. Hennicke

Abteilung Ökologie und Naturschutz, Biozentrum Grindel,

Universität Hamburg,

Martin-Luther-King Platz 3,

20146 Hamburg, Germany

K. Ludynia

Animal Demography Unit, Department of Zoology,

University of Cape Town,

Rondebosch,

7701 Cape Town, South Africa

\section{S. Riou}

Institute of Integrative and Comparative Biology,

University of Leeds,

Leeds LS2 9JT, UK

\section{S. Merino}

Departamento de Ecología Evolutiva,

Museo Nacional de Ciencias Naturales,

Consejo Superior de Investigaciones Científicas,

Madrid, Spain ranging from Antarctica to the tropical Indian Ocean. We did not detect parasites in 11 of these species, including one Antarctic, four subantarctic, two temperate, and four tropical species. On the other hand, two subantarctic species, thinbilled prions Pachyptila belcheri and dolphin gulls Larus scoresbii, were found infected. One of 28 thin-billed prions had a Plasmodium infection whose DNA sequence was identical to lineage P22 of Plasmodium relictum, and one of 20 dolphin gulls was infected with a Haemoproteus lineage which appears phylogenetically clustered with parasites species isolated from passeriform birds such as Haemoproteus lanii, Haemoproteus magnus, Haemoproteus fringillae, Haemoproteus sylvae, Haemoproteus payevskyi, and Haemoproteus belopolskyi. In addition, we found a high parasite prevalence in a single tropical species, the Christmas Island frigatebird Fregata andrewsi, where 56\% of sampled adults were infected with Haemoproteus. The latter formed a monophyletic group that includes a Haemoproteus line from Eastern Asian black-tailed gulls Larus crassirostris. Our results are in agreement with those showing that (a) seabirds are poor in hemosporidians and (b) latitude could be a determining factor to predict the presence of hemosporidians in birds. However, further studies should explore the relative importance of extrinsic and intrinsic factors on parasite prevalence, in particular using phylogenetically controlled comparative analyses, systematic sampling and screening of vectors, and within-species comparisons.

Keywords Avian hematozoa B Blood parasites . Hemoparasites $\cdot$ Innate immunity $\cdot$ Seabirds

\section{Introduction}

Parasites exert important ecological and evolutionary pressures on their hosts. Blood parasites (hematozoa) were 
considered to be organisms of low pathogenicity in wild populations, but it has been demonstrated that hematozoa can have important implications for bird community structure and conservation (e.g., van Riper et al. 1986), as well as life history traits of avian hosts (e.g., Merino et al. 2000; Hõrak et al. 2001; Sanz et al. 2001a, b; Sol et al. 2003; Marzal et al. 2005). Knowledge about the prevalence of hematozoa is thus essential for understanding the ecological and evolutionary implications of these parasites on their hosts and, ultimately, on ecosystems (see Sol et al. 2003).

Birds are infected by a number of intracellular blood parasites, including Hemosporidia of the genera Plasmodium, Haemoproteus, and Leucocytozoon, and Haemogregarinidae of the genus Hepatozoon and piroplasmids of the genus Babesia. It has been established that once birds become infected with hemosporidian parasites, they remain infected either for life or many years (Garnham 1966; Valkiūnas 2005).

The intracellular hematozoa occurring in vertebrates belong to the phylum Apicomplexa, and their life cycle generally consists of three major phases (Bush et al. 2001). Schizogony is an asexual phase in which multiple mitoses take place, resulting in daughter cells. Schizogony occurs within the vertebrate host and causes disease by destroying host erythrocytes (Plasmodium, Haemoproteus, Leucocytozoon) or leucocytes (Leucocytozoon, Hepatozoon). The remaining phases of the life cycle, gametogony and sporogony, occur within an arthropod vector and result in the production of infective sporozoites. Transmission can occur through different hematophagous arthropods. Plasmodium is transmitted by mosquitoes (Culicidae) and less commonly by sandflies (Psychodidae). Haemoproteus is transmitted by louse flies (Hippoboscidae) and biting midges (Ceratopogonidae) and Leucocytozoon by blackflies (Simulidae). Hepatozoon is most commonly transmitted by ticks (Ixodidae, Smith 1996).

The prevalence of infection varies greatly among different bird orders (e.g., Bennett et al. 1993a, b; Valkiūnas 2005), but the reasons for interspecific variation in parasite prevalence or diversity are still poorly understood (Scheuerlein and Ricklefs 2004). Absence or scarcity of blood parasites has been reported from avian groups such as seabirds (e.g., Peirce and Brooke 1993; Merino et al. 1997a; Merino and Minguez 1998; Engström et al. 2000), swifts (Tella et al. 1995), waders (Figuerola et al. 1996), raptors (e.g., Tella et al. 1996), and parrots (Masello et al. 2006). There is also some evidence that blood parasites are less common in certain habitats such as the Arctic tundra (e.g., Bennett et al. 1992), arid environments (e.g., Little and Earlé 1995; Valera et al. 2003), island environments (e.g., Little and Earlé 1994), or marine environments (e.g., Piersma 1997; Figuerola 1999; Jovani et al. 2001).

Most previous studies used blood smears to detect blood parasites. However, it has been suggested that blood smears may not detect parasites if the intensity is low (e.g., Plasmodium and Haemoproteus spp. during early spring; Valkiūnas 2005). Genetic methods, using sensitive polymerase chain reaction (PCR), can detect some parasitemia missed by blood smears (e.g., Feldman and Freed 1995; Bensch et al. 2000; Perkins and Schall 2002; Ricklefs et al. 2005; Parker et al. 2006; Merino et al. 2008). However, false negatives are not completely excluded by molecular methods (Gomez-Diaz et al. 2010). Furthermore, molecular methods are still inaccurate for the identification of the parasite species and should be combined with light microscopy (Valkiūnas et al. 2008).

In the present study, we used genetic methods to detect parasites in a suite of 14 seabird species, ranging from Antarctica to the tropical Indian Ocean. Specifically, we aimed to validate the hypothesis that hemosporidian blood parasite prevalences are low among seabirds and especially in cold climates.

\section{Methods}

\section{Study species}

Wilson's storm-petrels Oceanites oceanicus were sampled in their Antarctic breeding grounds at King George Island $\left(62^{\circ} 14^{\prime} \mathrm{S}, 58^{\circ} 40^{\prime} \mathrm{W}\right)$, during fieldwork described in detail previously (summarized in Quillfeldt 2004; Büßer et al. 2008; Gladbach et al. 2009). Out of previously collected blood samples (breeding season 1999-2000), we randomly selected samples of six males and six females for the present analysis. We observed no biting insects at the breeding grounds of Wilson's storm-petrels, the only ectoparasites found being the Mallophaga Philoceanus robertsi (Phthiraptera: Ischnocera; Quillfeldt et al. 2004a).

Subantarctic species were sampled at New Island, Falkland Islands $\left(51^{\circ} 43^{\prime} \mathrm{S}, 61^{\circ} 17^{\prime} \mathrm{W}\right)$. We included samples of two seasons (2007-2008 and 2008-2009) into the analysis for thin-billed prions Pachyptila belcheri, imperial shags Phalacrocorax atriceps, and southern rockhopper penguins Eudyptes chrysocome. General fieldwork techniques have been described in detail previously for thin-billed prions (e.g., Quillfeldt et al. 2003, 2007a, b, 2008) and southern rockhopper penguins (e.g., Poisbleau et al. 2008). Additionally, in 2008-2009, we collected samples from dolphin gulls Larus scoresbii, Magellanic penguins Spheniscus magellanicus, and gentoo penguins Pygoscelis papua. All adult birds in New Island were sampled at their nest when attending young chicks. Adults were captured by hand, blood-sampled and measured (for sample sizes, see Table 1). Potential arthropod vectors in the New Island seabird community include fleas Parapsyllus sp. that are common in nest burrows of thin-billed 
Table 1 Data on the bird species sampled in the present study

\begin{tabular}{|c|c|c|c|c|c|}
\hline Species & Scientific name & Breeding site & Number & Parasites found & Prevalence $^{\mathrm{a}}$ \\
\hline \multicolumn{6}{|l|}{ Antarctic } \\
\hline Wilson's storm-petrel & Oceanites oceanicus & King George Island $\left(62^{\circ} 14^{\prime} \mathrm{S}, 58^{\circ} 40^{\prime} \mathrm{W}\right)$ & $12(6 f, 6 m)$ & - & - \\
\hline \multicolumn{6}{|l|}{ Subantarctic } \\
\hline Rockhopper penguin & Eudyptes chrysocome & New Island $\left(51^{\circ} 43^{\prime} \mathrm{S}, 61^{\circ} 17^{\prime} \mathrm{W}\right)$ & $28(14 f, 14 m)$ & - & - \\
\hline Magellanic penguin & Spheniscus magellanicus & New Island $\left(51^{\circ} 43^{\prime} \mathrm{S}, 61^{\circ} 17^{\prime} \mathrm{W}\right)$ & $18(9 \mathrm{f}, 6 \mathrm{~m}, 2 \mathrm{u})$ & - & - \\
\hline Gentoo penguin & Pygoscelis papua & New Island $\left(51^{\circ} 43^{\prime} \mathrm{S}, 61^{\circ} 17^{\prime} \mathrm{W}\right)$ & $15(9 f, 6 m)$ & - & - \\
\hline Thin-billed prion & Pachyptila belcheri & New Island $\left(51^{\circ} 43^{\prime} \mathrm{S}, 61^{\circ} 17^{\prime} \mathrm{W}\right)$ & $28(12 \mathrm{~m}, 16 \mathrm{f})$ & $\begin{array}{l}\text { Plasmodium } \\
(N=1)\end{array}$ & $3.6 \pm 6.9 \%$ \\
\hline Imperial shag & Phalacrocorax atriceps & New Island $\left(51^{\circ} 43^{\prime} \mathrm{S}, 61^{\circ} 17^{\prime} \mathrm{W}\right)$ & $25(12 \mathrm{~m}, 13 \mathrm{f})$ & & - \\
\hline Dolphin gull & Larus scoresbii & New Island $\left(51^{\circ} 43^{\prime} \mathrm{S}, 61^{\circ} 17^{\prime} \mathrm{W}\right)$ & $20(10 \mathrm{~m}, 10 \mathrm{f})$ & $\begin{array}{l}\text { Haemoproteus } \\
(N=1)\end{array}$ & $5 \pm 9.5 \%$ \\
\hline \multicolumn{6}{|l|}{ Temperate } \\
\hline Cory's shearwater & Calonectris diomedea & Berlenga Island $\left(39^{\circ} 24^{\prime} \mathrm{N}, 9^{\circ} 30^{\prime} \mathrm{W}\right)$ & $15(7 f, 8 m)^{b}$ & - & - \\
\hline Manx shearwater & Puffinus puffinus & Skomer Island $\left(51^{\circ} 44^{\prime} \mathrm{N}, 5^{\circ} 17^{\prime} \mathrm{W}\right)$ & $12(6 f, 6 m)$ & - & - \\
\hline \multicolumn{6}{|l|}{ Tropical } \\
\hline Abbott's booby & Papasula abbotti & Christmas Island $\left(10^{\circ} 25^{\prime} \mathrm{S}, 105^{\circ} 40^{\prime} \mathrm{E}\right)$ & $12(6 f, 6 m)$ & - & - \\
\hline Red-footed booby & Sula sula rubripes & Christmas Island $\left(10^{\circ} 25^{\prime} \mathrm{S}, 105^{\circ} 40^{\prime} \mathrm{E}\right)$ & $12(6 f, 6 m)$ & - & - \\
\hline Brown booby & Sula leucogaster plotus & Christmas Island $\left(10^{\circ} 25^{\prime} \mathrm{S}, 105^{\circ} 40^{\prime} \mathrm{E}\right)$ & $12(6 f, 6 m)$ & - & - \\
\hline Red-tailed tropicbird & Phaethon rubricauda & Christmas Island $\left(10^{\circ} 25^{\prime} \mathrm{S}, 105^{\circ} 40^{\prime} \mathrm{E}\right)$ & $12(6 f, 6 m)$ & - & - \\
\hline $\begin{array}{l}\text { Christmas Island } \\
\text { frigatebird }\end{array}$ & Fregata andrewsi & Christmas Island $\left(10^{\circ} 25^{\prime} \mathrm{S}, 105^{\circ} 40^{\prime} \mathrm{E}\right)$ & $9(6 \mathrm{f}, 3 \mathrm{~m})$ & $\begin{array}{l}\text { Haemoproteus } \\
(N=5)\end{array}$ & $55.6 \pm 32.46 \%$ \\
\hline
\end{tabular}

$m$ males, $f$ females, $u$ unknown sex

${ }^{\text {a }}$ Prevalence $\pm 95 \%$ confidence interval

${ }^{\text {b }}$ Chick samples (age 18 to 36 days) of Cory's shearwater, all other samples were from breeding adults

prions and Magellanic penguins, as well as in gentoo penguin colonies (De Meillon 1952). Ixodes sp. ticks are abundant in nest burrows of Magellanic penguins and in imperial shag nesting areas. Although rockhopper penguins breed close to the imperial shags, ticks are not usually observed on this species (PQ \& JFM, pers. obs.).

Two temperate species were sampled. Cory's shearwater Calonectris diomedea chicks of 18 to 36 days of age were blood-sampled at Berlenga Island, Portugal $\left(39^{\circ} 24^{\prime} \mathrm{N}\right.$, $9^{\circ} 30^{\prime} \mathrm{W}$, see Quillfeldt and Masello 2004; Träger et al. 2006; Quillfeldt et al. 2007c) in August 2003. Manx shearwater Puffinus puffinus adults were blood-sampled at Skomer Island, Southwest Wales, UK (51 $\left.{ }^{\circ} 44^{\prime} \mathrm{N}, 5^{\circ} 17^{\prime} \mathrm{W}\right)$ (e.g., Quillfeldt et al. 2004b; Hamer et al. 2006; Riou and Hamer 2010; Riou et al. 2010). Possible vectors include fleas (Ornithopsylla laetitiae in the Manx shearwater and Xenopsylla gratiosa in Cory's shearwater); the trombiculid mite Neotrumbicula autumnalis, which is commonly found on Skomer; and Ixodes ticks (Brooke 1990; Gomez-Diaz et al. 2008).

Tropical species were sampled on Christmas Island (CI), Indian Ocean, Australia $\left(10^{\circ} 25^{\prime} \mathrm{S}, 105^{\circ} 40^{\prime} \mathrm{E}\right)$. Samples were taken from July to September 2007 and additional samples of CI frigatebirds were collected in May 2008.
Adults of the ground-breeding brown booby and red-tailed tropicbird were caught on their nests using a 1.2-m-long noose pole. Nests of the tree breeding CI frigatebird, Abbott's booby, and red-footed booby were accessed by tree climbing, and birds were captured on their nests by hand. After sampling, adult brown boobies, Abbott's boobies, and red-tailed tropicbirds were put back onto their nests, whereas CI frigatebirds and red-footed boobies were released from the ground and returned onto their nests within 2-7 min. Vectors here include mosquitoes Culicidae which are abundant all over the island and at the colonies of all study species. Louse flies Hippoboscidae were found on individuals of all study species but ticks Ixodidae were mainly found on the ground-breeding brown booby and red-tailed tropicbird.

Sample collection

All adults were sampled during the breeding season, on their nest or in their nest burrow, when incubating eggs or attending young. Each bird was individually marked with numbered rings or electronic tags in penguins, to avoid re-sampling. For each bird, a drop of blood was obtained from the brachial vein and preserved in $80 \%$ ethanol for 
DNA analyses. We used the same protocol in 2008-2009 except that samples were stored on FTA classic cards (Whatman International Ltd. UK).

\section{DNA analyses}

Blood samples preserved in ethanol were centrifuged at $13,000 \times \mathrm{g}$ for $15 \mathrm{~min}$. Afterwards, the supernatants were discarded and the pellets resuspended in distillated water, frozen, and lyophilized to remove ethanol. Genomic DNA from lyophilized samples was extracted using the following protocol: dried samples were resuspended in $250 \mu \mathrm{L}$ of SET buffer $(0.15 \mathrm{M} \mathrm{NaCl}, 0.05 \mathrm{M}$ Tris, $0.001 \mathrm{M}$ EDTA, $\mathrm{pH}=8)$, and SDS $20 \%(7 \mu \mathrm{L})$ and proteinase $\mathrm{K}(50 \mathrm{mg})$ were immediately added to the vials, maintaining the mix in an incubating shaker at $55^{\circ} \mathrm{C}$ overnight. The following day, ammonium acetate $4 \mathrm{M}(250 \mu \mathrm{L})$ was added to the vials at room temperature for $30 \mathrm{~min}$. Subsequently, vials were centrifuged at $13,000 \times g$ for $10 \mathrm{~min}$. After removing the pellet, DNA was precipitated with ethanol and resuspended in sterile water.

Partial amplification of the cytochrome $b$ gene was accomplished by PCR using the non-specific primers PALUF (5'-GGGTCAAATGAGTTTCTGG-3') and PALU-R (5'-DGGAACAATATGTARAGGAGT-3') for detection of Haemoproteus/Plasmodium species (see Martínez et al. 2009) and primers LDLd (5'-CATTCYACWGGTGCATCT TT-3') and LDRd (5'-CTGGATGWGATAATGGWGCA-3') for detection of Leucocytozoon (Merino et al. 2008).

PCR reactions consisted of $25-\mu \mathrm{L}$ reaction volumes containing $20 \mathrm{ng}$ template DNA, $50 \mathrm{mM} \mathrm{KCl}, 10 \mathrm{mM}$ Tris$\mathrm{HCl}, 1.5 \mathrm{MgCl}_{2}, 0.2 \mathrm{mM}$ of each dNTP, $0.5 \mu \mathrm{M}$ of each primer and 1.25 U of AmpliTaq Gold (Applied Biosystems, Foster City, CA, USA). The reactions were cycled at the following parameters using a thermal cycler (MasterCycler Personal, Eppendorf): $94^{\circ} \mathrm{C}$ for $10 \mathrm{~min}$ (polymerase activation), 40 cycles at $95^{\circ} \mathrm{C}$ for $40 \mathrm{~s}$, annealing temperature for $1 \mathrm{~min}, 72^{\circ} \mathrm{C}$ for $1 \mathrm{~min}$, and a final extension at $72^{\circ} \mathrm{C}$ for $10 \mathrm{~min}$. The annealing temperature was selected at $54^{\circ} \mathrm{C}$ and $58^{\circ} \mathrm{C}$ for primers PALU-F/PALU-R and LDLd/LDRd, respectively. All the DNA fragments obtained after PCR assays were recovered from agarose gels and subjected to direct sequencing. DNA fragments obtained were sequenced using an ABI 3130 (Applied Biosystems) automated sequencer. For potential cases of under-amplification (i.e., weak signal obtained), we repeated the PCR procedure under the same conditions. All of these samples were considered as negative because the second amplification failed to render a positive band. Thus, all samples rendering a clear PCR product were sequenced and identified to genus. A sample previously identified as infected by both methods of blood smear and molecular sequencing was included at each PCR as a positive control.
Fig. 1 Phylogenetic inference of the Plasmodium and Haemoproteus lineages found in thin-billed prions Pachyptila belcheri (Anja5p), Christmas Island frigatebirds Fregata andrewsi (katta), and dolphin gulls Larus scoresbii (Anja3d). Phylogenetic tree was obtained with the program MrBayes v3.2 using the substitution model $\mathrm{GTR}+\mathrm{I}+\mathrm{G}$ that was previously selected by means of jModelTest (see "Methods"). Accession numbers are indicated between parentheses and the three lineages isolated in the present study are marked in bold. Superscripted number 1-Plasmodium cuculus is not a valid species and still needs taxonomic description. Based on the present phylogeny, it is probably a Haemoproteus species

The three DNA sequences corresponding to Haemoproteus or Plasmodium lineages obtained from marine birds were aligned together with the other 84 sequences belonging to identified Haemoproteus or Plasmodium species previously listed in GenBank. The alignments were performed using the CLUSTALW algorithm implemented in BIOEDIT program (Hall 1999). The final alignment contained 765 positions and 89 taxa including two lineages of Leucocytozoon as outgroup. The alignments were analyzed using Bayesian inference implemented in the program MrBayes v3.2 (Ronquist and Huelsenbeck 2003) setting the substitution model GTR $+\mathrm{I}+\mathrm{G}$. The model was previously selected using corrected AIC implemented in jModelTest 0.0.1 (Posada 2008). Instead of setting the parameters I (proportion of invariant sites) and $\mathrm{G}$ ( $\alpha$ parameter of the gamma distribution) obtained from jModelTest, they were estimated by the MrBayes program selecting the "invgamma" option from the command "rates" as suggested by the authors of the program. Metropolis-coupled Markov chain Monte Carlo analyses were run for 20,000,000 generations and sampled every 1,000 generations. At the end of the analysis, we set the burn-in period to $50 \%$ where the chains reached stationary phase. The convergence of the parameters and topology was tested using the TRACER (Rambaut and Drummond 2007) and AWTY (Nylander et al. 2008; Wilgenbusch et al. 2004) applications, respectively. In both cases, the statistical data and graphs did not show lack of convergence. The consensus tree was estimated using 20,000 trees. Estimates of evolutionary divergence were conducted using the uncorrected p-distance test using the pair-wise deletion option implemented in MEGA4 (Tamura et al. 2007).

\section{Microscopic analyses}

A drop of blood from each bird was immediately smeared and air-dried, fixed with methanol, and later stained with Giemsa stain $(1 / 10 v / v)$ for $30 \mathrm{~min}$. Blood smears from birds found positive for blood parasite infections by molecular analyses were scanned using an optic microscope (Olympus BX41). Parasites were searched at 100× under oil amplification following the methods described in Merino et al. (1997b). 


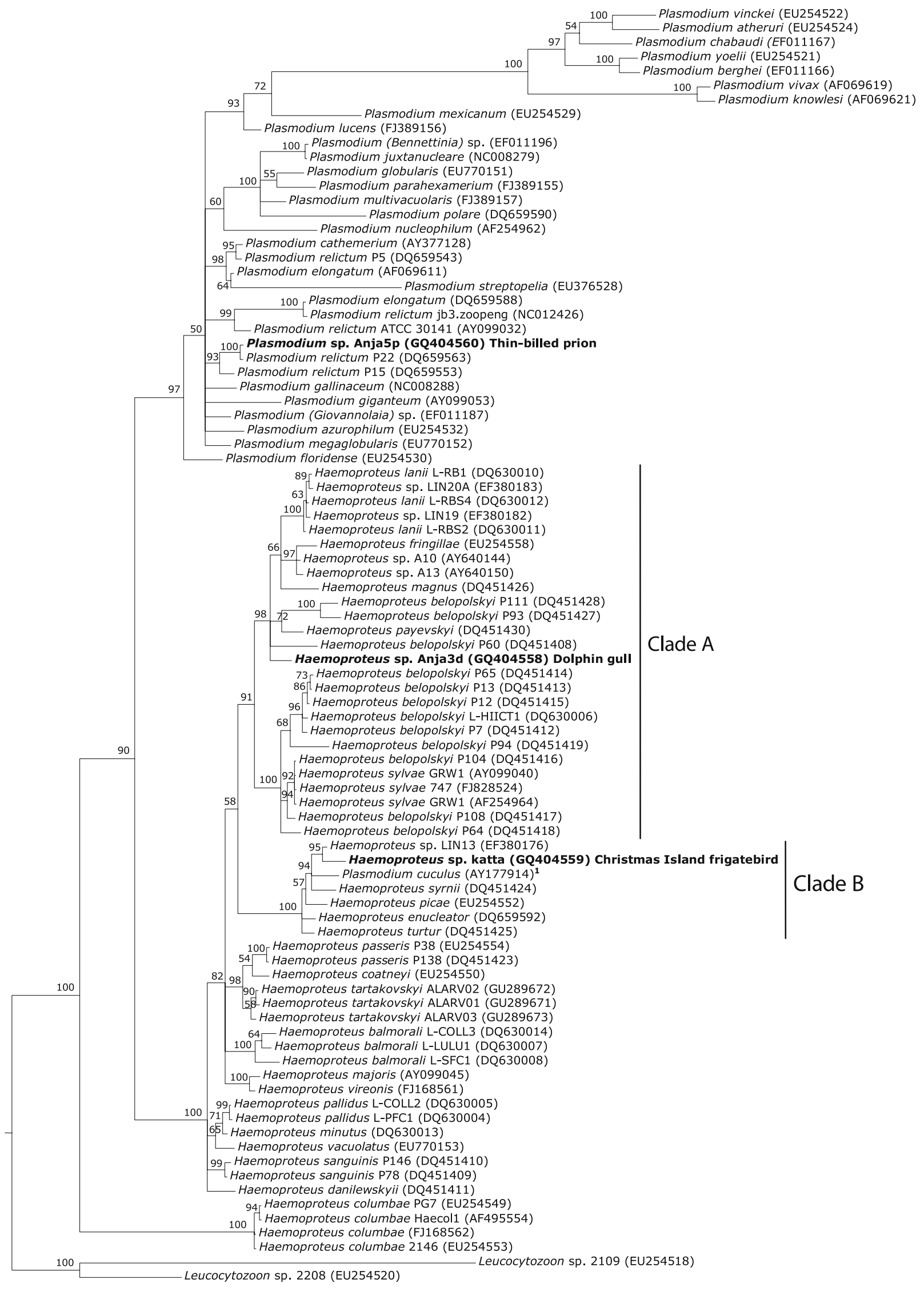




\section{Results}

Parasites detected

We did not detect parasites in 11 of the 14 species, including one Antarctic, four subantarctic, two temperate, and four tropical species. Blood parasites were found in two species from subantarctic areas: one of 20 dolphin gulls (a female) was infected with Haemoproteus (GenBank accession number GQ404558) and one of 28 thinbilled prions (a female) was infected with Plasmodium (GenBank accession number GQ404560). The prevalence and the $95 \%$ confidence interval of gulls and prions were $5.0 \pm 9.5 \%$ and $3.6 \pm 6.9 \%$, respectively. However, we did not detect hemoparasites in the blood smears of the infected dolphin gull or the infected thin-billed prion (two smears from each of these birds were scanned in search of blood parasites).

Only one tropical species had higher prevalence. Five of nine Christmas Island frigatebirds $(55.6 \pm 32.46 \%)$ were infected with Haemoproteus (GenBank accession number GQ404559).

\section{Phylogenetic analysis}

Bayesian inference indicated that the Plasmodium isolated (Anja5p) from thin-billed prion blood forms a monophyletic clade (support of 93\%) together with the lineages P22 and P15 identified as Plasmodium relictum (Fig. 1). The Plasmodium lineages P22 and Anja5p were identical and the genetic distance between Plasmodium lineages Anja5p and P15 was 2.2\%. The Haemoproteus isolated from dolphin gull blood (Anja3d), in contrast, was clustered into a well-supported (91\%) monophyletic group (named clade A) containing diverse Haemoproteus species (from Haemoproteus lanii L-RB1 to Haemoproteus belopolskyi P64, see Fig. 1). The genetic distance between Anja3d isolated and the other Haemoproteus species included in clade A ranged between $2.7 \%$ for A10 Haemoproteus isolate and $7.7 \%$ for P65 and P13 isolates identified as H. belopolskyi (Fig. 1). Finally, the Haemoproteus line from Christmas Island frigatebird blood (katta isolate) formed a monophyletic group (named clade B and with support of $100 \%$ ) with Haemoproteus species isolated from non-passeriform birds (Haemoproteus syrnii, Haemoproteus picae, Haemoproteus enucleator, and Haemoproteus turtur). The LIN13 lineage isolated from Eastern Asian black-tailed gulls Larus crassirostris was the closer sequence grouped with the katta lineage and the genetic distance between them was $1.4 \%$ (Fig. 1). Finally, the clusters where the Haemoproteus isolates from Christmas Island frigatebird (katta) and dolphin gull (Anja3d) are found are sister groups (Fig. 1).

\section{Discussion}

Haemoproteus

Haemoproteus are globally distributed in birds with about 100 named species (Peirce 2005) and within seabirds Haemoproteus parasites are especially common in frigatebirds (Lowery 1971; Work and Rameyer 1996; Padilla et al. 2006) and gulls (Peirce 1981; Ruiz et al. 1995; Bosch et al. 1997; Padilla et al. 2006). Thus, our present findings of a Haemoproteus infection in a frigatebird and a gull are in agreement with this pattern. The Haemoproteus isolate from Christmas Island frigatebird (katta) appears to have evolved from an original ancestor specialized in nonpasseriform species. The close relation with the Haemoproteus lineage found in L. crassirostris points to a posterior specialization phenomenon involving marine birds (Fig. 1). However, the only Haemoproteus infection detected in L. scoresbii was clustered with parasite lineages isolated from birds belonging to Passeriformes. The infection was undetected in blood smears, implying a very low intensity of infection. This fact, along with the result of the phylogenetic analysis which groups this parasite species with those infecting passeriform birds (Fig. 1), suggests that it may be a paratenic or cross infection still not totally, or recently established in this bird (see Beadell et al. 2004; Merino et al. 2008).

In general, Haemoproteus parasites are considered relatively benign in birds. Two seabird species affected by Haemoproteus have been studied in detail. In magnificent frigatebirds Fregata magnificens, 16\% of the males were infected with Haemoproteus iwa, but all infections were light ( $<1 \%$ of erythrocytes) and were thus classified as chronic (Madsen et al. 2007). In yellow-legged gulls, Martínez-Abrain et al. (2002) found significant differences in Haemoproteus lari prevalence between two breeding colonies. However, the birds of both colonies were in equally good body condition and had similar clutch sizes. Further, the intensity of $H$. lari infection was not correlated with body condition or egg volume (Martínez-Abrain et al. 2002), suggesting that $H$. lari parasites had little effect on the health of the gulls under normal conditions.

Studies in other birds also suggest that Haemoproteus numbers are normally kept low by natural immunity and only tend to multiply under stress, including other diseases. It has therefore been suggested that increasing Haemoproteus parasitemia can serve as a valuable indicator of an underlying disease (e.g., Remple 2004) or stressful conditions (Valkiūnas 2005). However, experimental studies suggest important detrimental effects of Haemoproteus blood parasites on bird fitness (Merino et al. 2000; Marzal et al. 2005). In magnificent frigatebirds F. magnificens, males infected with $H$. iwa had a less intensely colored red 
inflatable gular pouch (Madsen et al. 2007), which is an important ornament used in mate choice. This suggests that even light infections can influence the reproductive success of individuals and thus be subject to intense selection.

\section{Plasmodium}

Bennett et al. (1993a) listed 34 species of Plasmodium in birds. Although avian Plasmodium and their vectors are distributed worldwide except in extreme habitats, their prevalence is much lower than that of other avian blood parasites such as Haemoproteus and Leucocytozoon. Only one species, $P$. relictum, has been detected in wild seabirds (Fantham and Porter 1944; Laird 1950). P. relictum is the most common species of Plasmodium in avian hosts, with a wide distribution both geographically and with respect to host phylogeny. Other species, Plasmodium circumflexum and Plasmodium cathemerium, have been associated with mortality in captive penguins in zoos (Bennett et al. 1993b), but have not been reported in wild seabirds, to our knowledge.

In the present study, we detected a Plasmodium infection in one of 28 thin-billed prions, but no parasites were found in blood smears from that bird. On the one hand, the phylogenetic analysis suggested that this lineage belongs to $P$. relictum species because it is included within a monophyletic clade (support of 93\%) together with two lines of $P$. relictum isolated in birds belonging to Passeriformes (P22 and P15). In fact, the mean genetic divergence between the Plasmodium isolated from thin-billed prion (Anja5p) and the P22 Plasmodium isolate is $0 \%$. However, other $P$. relictum isolates displayed on the phylogenetic tree are not clustered into the same monophyletic clade, showing genetic distances as high as $7.6 \%$ between isolates. Taking into account that (a) Perkins (2000) suggested that $3 \%$ was a reasonable level of specific differentiation, based primarily on differentiation among vertebrate species, and (b) named species of malaria parasite that infect primates differ by as little as 1\% sequence divergence (Escalante et al. 1998), the value of genetic distance obtained suggests the occurrence of different genetic species under the same parasite morphospecies. On the other hand, the very low prevalence and intensity of infection suggest this to be a secondary origin, as has been suggested to occur in some ancient birds belonging to Procellariiformes, Pelecaniformes, and Sphenisciformes orders (e.g., Valkiūnas 2005). Thus, the infection might have passed to thin-billed prion from another species and is at present not a well-established parasite for this host species.

Given the highly pelagic distribution of thin-billed prions, an infection would most likely have occurred during the breeding season, when the breeding birds come ashore. There is a range of possible hosts of hemoparasites at New Island, where the source of the Plasmodium isolated from thin-billed prions might be found. These include migratory and resident waders, songbirds, and several duck and goose species, as well as other seabirds breeding at New Island which were not sampled (e.g., kelp gulls Larus dominicanus and black-browed albatross Thalassarche diomedea).

\section{Outlook}

In a recent review regarding the apparent lack of blood parasites in some avian species, Martínez-Abrain et al. (2004) discussed the main hypotheses to explain this absence: (1) the absence or scarcity of proper vectors, (2) a highly specific association between host and parasites with host switching being infrequent (host-parasite assemblage), (3) host immunological capabilities preventing infection by parasites, and (4) competitive exclusion of blood parasite vectors mediated by ectoparasites.

In line with hypothesis (1), blood parasites are generally absent from Antarctic and arctic seabirds, whereas in milder climates, about one third of the seabird species studied so far had hemoparasites. This may be due partly to the absence of appropriate vectors in saline environments (Figuerola 1999). Barbosa and Palacios (2009) noted that the two blood parasites present in sub-Antarctic islands, are absent in Antarctica and suggested that this mirrors the absence of suitable vectors in Antarctica (Merino et al. 1997a). Latitudinal gradients in the prevalence of blood parasites infecting some bird species (Merino et al. 2008) suggest that latitude could also influence the presence of these parasites in seabirds, and more detailed analyses on different geographic areas and bird families should be conducted in this regard.

Although our data are in agreement with previous studies supporting hypothesis (1), the confidence intervals of the computed prevalence suggest that the interpretation of these data should be performed only in a qualitative sense. Further studies should explore the relative importance of extrinsic and intrinsic factors on parasite prevalence, in particular using phylogenetically controlled comparative analyses, systematic sampling and screening of vectors, and within-species comparisons.

Acknowledgments This work was made possible by a Synthesys grant (ES-TAF 5680). We would like to thank for assistance at New Island: Hendrika (Riek) van Noordwijk, Maud Poisbleau, Laurent Demongin, and Andreas Michalik; at Christmas Island: Lena Braun, Kai Flachsbarth, Nina Dehnhard, Juan Navarro, Michael and Irene Spindler, and Mariska van der Stap; and in the laboratory: Jessica Herrero. We would like to thank Keith Hamer for supervising the fieldwork at Skomer Island. The New Island Conservation Trust and Ian, Maria and Georgina Strange and Dan Birch facilitated fieldwork at New Island, which was approved and co-funded by the Falkland Islands Government (Environmental Planning Office). Fieldwork on Christmas Island was conducted within the framework of the Christmas Island Seabird Project (www.seabirdproject.cx) which was supported by the University of Hamburg Research Fund, Christmas Island Tourist Association, Island Explorer Holidays, CI Territory Week Committee, and CI Island Care. Fieldwork was approved by Parks 
Australia North Christmas Island and Darwin and the Animal Ethics Committee of the Charles Darwin University, Darwin, Australia. Parks Australia North Christmas Island helped with logistics. During the preparation of this work, JM and SM were supported by project CGL2009-09439 from the Spanish Ministry of Science and Technology and PQ by a grant from DFG, Germany (Qu 148/1-ff). We are grateful to two anonymous referees for constructive comments on this manuscript.

Open Access This article is distributed under the terms of the Creative Commons Attribution Noncommercial License which permits any noncommercial use, distribution, and reproduction in any medium, provided the original author(s) and source are credited.

\section{References}

Barbosa A, Palacios MJ (2009) Health of Antarctic birds: a review of their parasites, pathogens and diseases. Polar Biol 32:1095-1115

Beadell JS, Gering E, Austin J, Dumbacher JP, Peirce MA, Pratt TK, Atkinson CA, Fleischer RC (2004) Prevalence and differential host-specificity of two avian blood parasite genera in the Australo-Papuan region. Mol Ecol 13:3829-3844

Bennett GF, Montgomerie R, Seutin G (1992) Scarcity of haematozoa in birds breeding on the Arctic tundra of North America. Condor 94:289-292

Bennett GF, Bishop MA, Peirce MA (1993a) Checklist of the avian species of Plasmodium Marchiafava and Celli, 1885 (Apicomplexa) and their distribution by avian family and Wallacean life zones. Syst Parasitol 26:171-179

Bennett GF, Peirce MA, Ashford RW (1993b) Avian haematozoa: mortality and pathogenicity. J Nat Hist 27:993-1001

Bensch S, Stjernman M, Hasselquist D, Ostman O, Hansson B, Westerdahl H, Pinheiro RT (2000) Host specificity in avian blood parasites: a study of Plasmodium and Haemoproteus mitochondrial DNA amplified from birds. Proc R Soc Lond B 267:1583-1589

Bosch M, Figuerola J, Cantos FJ, Velarde R (1997) Intracolonial differences in the infestation by Haemoproteus lari on yellowlegged gulls Larus cachinnans. Ornis Fenn 74:105-112

Brooke M (1990) The Manx shearwater. Poyser T \& AD, London

Bush AO, Fernández JC, Esch GW, Seed JR (2001) Parasitism. The diversity and ecology of animal parasites. Cambridge University Press, Cambridge

Büßer C, Hahn S, Gladbach A, Lorenz S, Nordt A, Quillfeldt P, Schmoll T, Peter H-U (2008) A decade of fundamental ecological research on storm-petrels at the Tres Hermanos colony, Potter Peninsula, King George Island. Ber Polarforsch 571:168-175

De Meillon B (1952) The fleas of seabirds in the Southern Ocean. ANARE Report Series B 1 (Zoology)

Engström H, Dufva R, Olsson G (2000) Absence of haematozoa and ectoparasites in a highly sexually ornamented species, the crested auklet. Waterbirds 23:486-488

Escalante AA, Freeland DE, Collins WE, Lal AA (1998) The evolution of primate malaria parasites based on the gene encoding cytochrome $\mathrm{b}$ from the linear mitochondrial genome. Proc Nat Acad Sci USA 95:8124-8129

Fantham HB, Porter A (1944) On a Plasmodium (Plasmodium relictum var. spheniscidae $\mathrm{n}$. var.) observed in four species of penguins. Proc Zool Soc Lond 114:279-292

Feldman RA, Freed LA (1995) A PCR test for avian malaria in Hawaiian birds. Mol Ecol 4:673

Figuerola J (1999) Effects of salinity on rates of infestation of waterbirds by haematozoa. Ecography 22:681-685

Figuerola JA, Velarde A, Bertolero A, Cerda F (1996) Abwesenheit von Haematozoa bei einer Brutpopulation des Seeregenpfeifers Charadrius alexandrinus in Nordspanien. J Ornithol 137:523-525
Garnham PCC (1966) Malaria parasites and other haemosporidia. Blackwell, Oxford

Gladbach A, Braun C, Nordt A, Peter H-U, Quillfeldt P (2009) Chick provisioning and nest attendance of male and female Wilson's storm petrels Oceanites oceanicus. Polar Biol 32:1315-1321

Gomez-Diaz E, Navarro J, Gonzales-Solis J (2008) Ectoparasite community structure on three closely related seabird hosts: a multiscale approach combining ecological and genetic data. Ecography 31:477-489

Gomez-Diaz E, Doherty PF Jr, Duneau D, McCoy KD (2010) Cryptic vector divergence masks vector-specific patterns of infection: an example from the marine cycle of Lyme borreliosis. Evol Appl 3:391-401

Hall TA (1999) BioEdit: a user-friendly biological sequence alignment editor and analysis program for Windows 95/98/NT. Nucleic Acids Sympos Ser 41:95-98

Hamer KC, Quillfeldt P, Masello JF, Fletcher KL (2006) Sex differences in provisioning rules: responses of Manx shearwaters to supplementary chick feeding. Behav Ecol 17:132-137

Hõrak P, Ots I, Vellau H, Spottiswoode C, Møller AP (2001) Carotenoidbased plumage coloration reflects hemoparasite infection and local survival in breeding great tits. Oecologia 126:166-173

Jovani R, Tella JL, Forero MG, Bertellotti M, Blanco G, Ceballos O, Donazar JA (2001) Apparent absence of blood parasites in the Patagonian seabird community: is it related to the marine environment? Waterbirds 24:430-433

Laird M (1950) Some blood parasites of New Zealand birds. Zool Pub Victoria Univ College 5:1-20

Little RM, Earlé RA (1994) Lack of avian haematozoa in the Phasianinae of Robben Island. Ostrich 65:343-344

Little RM, Earlé RA (1995) Sandgrouse (Pterocleidae) and sociable weavers Philetarius socius lack avian haematozoa in semi-arid regions of South Africa. J Arid Environ 30:367-370

Lowery RS (1971) Blood parasites of vertebrates on Aldabra. Phil Trans R Soc Lond B 260:577-580

Madsen VG, Iezhova TA, Mercade C, Sanchez M, Osorno JL (2007) Testosterone levels and gular pouch coloration in courting magnificent frigatebird (Fregata magnificens): variation with age-class, visited status and blood parasite infection. Horm Behav 51:156-163

Martínez J, Martínez de la Puente J, Herrero J, Del Cerro S, Lobato E, Rivero de Aguilar J, Vasquez RA, Merino S (2009) A restriction site to differentiate Plasmodium and Haemoproteus infections in birds: on the inefficiency of general primers for detection of mixed infections. Parasitology 136:713-22

Martínez-Abrain A, Merino S, Oro D, Esparza B (2002) Prevalence of blood parasites in two western-Mediterranean local populations of the yellow-legged gull Larus cachinnans michahellis. Ornis Fenn 79:34-40

Martínez-Abrain A, Esparza B, Oro D (2004) Lack of blood parasites in bird species: does absence of blood parasite vectors explain it all? Ardeola 51:225-232

Marzal A, de Lope F, Navarro C, Møller AP (2005) Malarial parasites decrease reproductive success: an experimental study in a passerine bird. Oecologia 142:541-545

Masello JF, Choconi G, Seghal RNM, Tell L, Quillfeldt P (2006) Blood and intestinal parasites in wild Psittaciformes: a case study of burrowing parrots (Cyanoliseus patagonus). Orn Neotropical 17:515-529

Merino S, Minguez E (1998) Absence of hematozoa in a breeding colony of the storm petrel Hydrobates pelagicus. Ibis 140:180-181

Merino S, Barbosa A, Moreno J, Potti J (1997a) Absence of haematozoa in a wild chinstrap penguin Pygoscelis antarctica population. Polar Biol 18:227-228

Merino S, Potti J, Fargallo JA (1997b) Blood parasites of some passerine birds from central Spain. J Wildl Dis 33:638-641 
Merino S, Moreno J, Sanz JJ, Arriero E (2000) Are avian blood parasites pathogenic in the wild? A medication experiment in blue tits (Parus caeruleus). Proc R Soc Lond B 267:2507-2510

Merino S, Moreno J, Vásquez RA, Martínez J, Sánchez-Monsálvez I, Estades CF, Ippi S, Sabat P, Rozzi R, McGehee S (2008) Haematozoa in forest birds from southern Chile: latitudinal gradients in prevalence and parasite lineage richness. Austral Ecol 33:329-340

Nylander JA, Wilgenbusch JC, Warren DL, Swofford DL (2008) AWTY (Are We There Yet): a system for graphical exploration of MCMC convergence in Bayesian phylogenetics. Bioinformatics 24:581-583

Padilla LR, Whiteman NK, Merkel J, Huyvert KP, Parker PG (2006) Health assessment of seabirds on Isla Genovesa, Galápagos. Ornithol Monogr 60:86-97

Parker PG, Whiteman NK, Miller RE (2006) Conservation medicine on the Galápagos Islands: partnerships among behavioral, population, and veterinary scientists. Auk 123:625-638

Peirce MA (1981) Haematozoa of British birds. VI. Redescription of Haemoproteus larae Yakunin from the lesser black-backed gull Larus fuscus. J Nat Hist 15:459-462

Peirce MA (2005) A checklist of the valid avian species of Babesia (Apicomplexa: Piroplasmorida), Haemoproteus, Leucocytozoon (Apicomplexa: Haemosporida), and Hepatozoon (Apicomplexa: Haemogregarinidae). J Nat Hist 39:3621-3632

Peirce MA, Brooke M (1993) Failure to detect blood parasites in seabirds from the Pitcairn Islands. Seabird 15:72-74

Perkins SL (2000) Species concepts and malaria parasites: detecting a cryptic species of Plasmodium. Proc Royal Soc London B 267:2345-2350

Perkins SL, Schall JJ (2002) A molecular phylogeny of malarial parasites recovered from cytochrome $\mathrm{b}$ gene sequences. J Parasitol 88:978

Piersma T (1997) Do global patterns of habitat use and migration strategies co-evolve with relative investment in immunocompetence due to spatial variation in parasites pressure? Oikos 80:623-631

Poisbleau M, Demongin L, Strange IJ, Otley H, Quillfeldt P (2008) Aspects of the breeding biology of the southern rockhopper penguin Eudyptes c. chrysocome and new consideration on the intrinsic capacity of the A-egg. Polar Biol 31:925-932

Posada D (2008) jModelTest: phylogenetic model averaging. Mol Biol Evol 25:1253-1256

Quillfeldt P (2004) Wilson's storm-petrel. In: Riffenburgh B (ed) Encyclopedia of the Antarctic. Routledge, New York, pp 1081-1084

Quillfeldt P, Masello JF (2004) Context-dependent honest begging in Cory's shearwaters (Calonectris diomedea): influence of food availability. Acta Ethol 7:73-80

Quillfeldt P, Masello JF, Strange IJ (2003) Breeding biology of the thin-billed prion Pachyptila belcheri at New Island, Falkland Islands, in the poor season 2002/2003: egg desertion, breeding success and chick provisioning. Polar Biol 26:746-752

Quillfeldt P, Masello JF, Möstl E (2004a) Blood chemistry in relation to nutrition and ectoparasite load in Wilson's storm-petrels Oceanites oceanicus. Polar Biol 27:168-176

Quillfeldt P, Masello JF, Hamer KC (2004b) Sex differences in provisioning rules and honest signalling of need in Manx shearwaters Puffinus puffinus. Anim Behav 68:613-620

Quillfeldt P, Strange IJ, Masello JF (2007a) Sea surface temperatures and behavioural buffering capacity in thin-billed prions Pachyptila belcheri: breeding success, provisioning and chick begging. J Avian Biol 38:298-308

Quillfeldt P, Strange IJ, Segelbacher G, Masello JF (2007b) Male and female contributions to provisioning rates of thin-billed prions Pachyptila belcheri in the South Atlantic. J Ornithol 148:367-372

Quillfeldt P, Träger I, Griffith K, Buchanan KL, Masello JF (2007c) Is sex-specific mass gain in Cory's shearwaters Calonectris dio- medea related to begging and steroid hormone expression? Behav Ecol Sociobiol 61:793-800

Quillfeldt P, McGill RAR, Strange IJ, Masello JF, Weiss F, Brickle P, Furness RW (2008) Stable isotope analysis reveals sexual and environmental variability and individual consistency in foraging of thin-billed prions. Mar Ecol Prog Ser 373:137-148

Rambaut A, Drummond AJ (2007) Tracer v1.4. Available from http:/ beast.bio.ed.ac.uk/Tracer. Accessed 10 June 2010

Remple JD (2004) Intracellular hematozoa of raptors: a review and update. J Avian Med Surg 18:75-88

Ricklefs RE, Swanson BL, Fallon SM, Martinez-Abrain A, Scheuerlein A, Gray J, Latta SC (2005) Community relationships of avian malaria parasites in southern Missouri. Ecol Monogr 75:543-559

Riou S, Hamer KC (2010) Lipid metabolism, begging behaviour and nestling obesity in a pelagic seabird. Funct Ecol 24:340-346

Riou S, Chastel O, Lacroix A, Hamer KC (2010) Stress and parental care: prolactin responses to acute stress throughout the breeding cycle in a long-lived bird. Gen Comp Endocrinol 168(1):8-13

Ronquist F, Huelsenbeck JP (2003) MrBayes 3: Bayesian phylogenetic inference under mixed models. Bioinformatics 19:1572-1574

Ruiz X, Oro D, Gonzales-Solis J (1995) Incidence of a Haemoproteus lari parasitemia in a threatened gull: Larus audouinii. Ornis Fenn 72:159-164

Sanz JJ, Arriero E, Moreno J, Merino S (2001a) Female hematozoan infection reduces hatching success but not fledging success in pied flycatchers Ficedula hypoleuca. Auk 118:750-755

Sanz JJ, Arriero E, Moreno J, Merino S (2001b) Interactions between hemoparasite status and female age in the primary reproductive output of pied flycatchers. Oecologia 126:339-344

Scheuerlein A, Ricklefs RE (2004) Prevalence of blood parasites in European passeriform birds. Proc R Soc Lond B 271:1363-1370

Smith TG (1996) The genus Hepatozoon (Apicomplexa: Adeleina). J Parasitol 82:565-585

Sol D, Jovani R, Torres J (2003) Parasite mediated mortality and host immune response explain age-related differences in blood parasitism in birds. Oecologia 135:542-547

Tamura K, Dudley J, Nei M, Kumar S (2007) MEGA4: molecular evolutionary genetics analysis (MEGA) software version 4.0. Mol Biol Evol 24:1596-1599

Tella JL, Cortazar C, Gajon A, Osacar JJ (1995) Apparent lack of effects of a high louse-fly infestation (Diptera, Hippoboscidae) on adult colonial alpine swifts. Ardea 83:435-439

Tella JL, Forero MG, Gajón A, Hiraldo F, Donázar JA (1996) Absence of blood-parasitization effects on lesser kestrel fitness. Auk 113:253256

Träger I, Masello JF, Mundry R, Quillfeldt P (2006) Do acoustical parameters of begging calls of Cory's shearwaters Calonectris diomedea reflect chick body condition? Waterbirds 29:315-320

Valera F, Carrillo CM, Barbosa A, Moreno E (2003) Low prevalence of haematozoa in trumpeter finches Bucanetes githagineus from south-eastern Spain: additional support for a restricted distribution of blood parasites in arid lands. J Arid Environ 55:209-213

Valkiūnas G (2005) Avian malaria parasites and other haemosporidia. CRC, Boca Raton

Valkiūnas G, Iezhova TA, Krizanauskiene A, Palinauskas V, Seghal RNM, Bensch S (2008) A comparative analysis of microscopy and PCRbased detection methods for blood parasites. J Parasitol 94:1395-1401

van Riper C, van Riper SG, Goff ML, Laird M (1986) The epizootiology and ecological significance of malaria in Hawaiian land birds. Ecol Monogr 56:327-344

Wilgenbusch JC, Warren DL, Swofford DL. (2004) AWTY: a system for graphical exploration of MCMC convergence in Bayesian phylogenetic inference. http://ceb.csit.fsu.edu/awty. Accessed 10 June 2010

Work TM, Rameyer RA (1996) Haemoproteus iwa n. sp. in Great Frigatebirds (Fregata minor [Gmelin]) from Hawaii: parasite morphology and prevalence. J Parasitol 82:489-491 